\title{
THE CONTENT OF ASCORBIC AND DEHYDROASCORBIC ACIDS AND VITAMIN C IN NON-PRESERVED JUICES, DEPENDING ON THEIR TYPE AND STORAGE TIME
}

\author{
Małgorzata Ewa Drywieńn', Joanna Frackiewicz', Sylwia Szpoton ${ }^{1}$
}

${ }^{1}$ Warsaw University of Life Sciences (WULS), Institute of Human Nutrition Sciences,

Department of Human Nutrition, Warsaw, Poland

\begin{abstract}
Background. Vitamin $\mathrm{C}$ is one of the most important water-soluble vitamins. It is responsible for many important functions in the body, including: it has a positive effect on maintaining immunity, protects the body against free radicals, and also participates in the synthesis of hormones. Juices can be a good source of this vitamin. Most of the juices available on the market are processed products. Untreated juices, which do not contain added preservatives, sugar and are not pasteurized, constitute a smaller group on the market. Therefore, this group of juices can be a valuable product in human nutrition.

Objective. The aim of the study was to analyze the content of ascorbic acid (AA), dehydroascorbic acid (DHAA) and vitamin $\mathrm{C}$ (TAA) in non-preserved juices, depending on their type and storage time.

Material and methods. The analysis of TAA, AA and DHAA content in juices was carried out in ten types of nonpreserved juices from two companies (A and B), purchased in a chain of retail outlets. The analyzed juices in company A were: sauerkraut and carrot, grapefruit, orange, apple and mandarin, while in company B: orange, apple, apple and quince, grapefruit and mandarin. In test 1 , the first ten juices were analyzed, in test 2 - another ten juices after one month, in test 3 - juices from test 2 were used, and three days after opening the package and storing the juices in standard refrigeration conditions, the stability test of AA was analyzed. The AA and TAA contents were determined using the high performance liquid chromatography (HPLC) method. The DHAA content was calculated by subtracting the AA content from the TAA content.

Results. The highest TAA content was found in citrus juices, i.e. grapefruit, orange and mandarin, and the lowest in sauerkraut and carrot juices and apple juice. Moreover, ascorbic acid in apple juice was characterized by the lowest durability.

Conclusions. In the production of non-preserved apple juice, consideration should be given to the natural protection of ascorbic acid by the addition of citrus or other fruit juice, vegetable juice or by using a mild technology in the production process.
\end{abstract}

Key words: vitamin C, ascorbic acid, dehydroascorbic acid, non-preserved juices

\section{STRESZCZENIE}

Wprowadzenie. Witamina $\mathrm{C}$ jest jedną z najważniejszych witamin rozpuszczalnych w wodzie. Odpowiedzialna jest za wiele ważnych funkcji w organizmie m.in.: wpływa korzystnie na utrzymanie odporności, chroni organizm przed działaniem wolnych rodników, a także ma udział w syntezie hormonów. Soki mogą stanowić dobre źródło tej witaminy. Większość dostępnych na rynku soków, to produkty przetworzone. Mniejszą grupę na rynku stanowią soki niepoddane utrwaleniu, które nie zawierają dodatku konserwantów, cukru i nie są poddawane procesowi pasteryzacji. W związku $\mathrm{z}$ tym ta grupa soków może być wartościowym produktem w żywieniu człowieka.

Cel badań. Celem pracy była analiza zawartości kwasu askorbinowego (AA), dehydroaskorbinowego (DHAA) oraz witaminy C (TAA) w sokach niepoddanych utrwaleniu, w zależności od ich rodzaju oraz czasu przechowywania.

Material i metody. Analizę zawartości TAA oraz AA i DHAA przeprowadzono w dziecięciu rodzajach soków niepoddanych utrwaleniu produkcji dwóch firm (A i B), zakupionych w sieci placówek handlowych. Analizowanymi sokami firmy A były: sok z kiszonej kapusty i marchwi, grejpfruta, pomarańczy, jabłka i mandarynki, natomiast, produkcji firmy B: sok z pomarańczy, jabłek, jabłek i pigwy, grejpfruta i mandarynki. W teście 1 analizie poddano pierwsze dziesięć soków, w teście 2 - po upływie miesiąca - kolejne dziesięć soków, w teście 3 - wykorzystano soki z testu 2 i po upływie trzech dni od otwarcia opakowania i przechowywania soków w standardowych warunkach chłodniczych, poddano

Corresponding author: Joanna Frąckiewicz, Szkoła Główna Gospodarstwa Wiejskiego w Warszawie, Instytut Nauk o Żywieniu Człowieka, Katedra Żywienia Człowieka, ul. Nowoursynowska 159C, 02-776 Warszawa, Polska, tel. +48 22 5937125, e-mail: joanna_frackiewicz@sggw.edu.pl

(C) Copyright by the National Institute of Public Health NIH - National Research Institute 
analizie sprawdzenia trwałości AA. Zawartość AA i TAA w sokach oznaczano metodą wysokosprawnej chromatografii cieczowej (HPLC). Zawartość DHAA obliczano odejmując oznaczoną zawartość AA od zawartości TAA.

Wyniki. Największą zawartością witaminy $\mathrm{C}$ charakteryzowały się soki cytrusowe, tj. z grejpfruta, pomarańczy i mandarynki, a najmniejszą soki z kapusty kiszonej i marchwi oraz sok jabłkowy. Ponadto kwas askorbinowy w soku jabłkowym cechował się najmniejszą trwałością.

Wnioski. W produkcji soku jabłkowego niepoddanego utrwaleniu należałoby rozważyć naturalną ochronę kwasu askorbinowego poprzez dodatek soku z owoców cytrusowych lub innych owoców, warzyw lub poprzez zastosowanie łagodnej technologii w procesie produkcji.

Słowa kluczowe: witamina $C$, kwas askorbinowy, kwas dehydroaskorbinowy, soki niepoddane utrwaleniu

\section{INTRODUCTION}

Fruit and some vegetable juices are a significant sources of vitamin $\mathrm{C}$ in human diet. Vitamin $\mathrm{C}$ is the collective term for L-ascorbic acid (product of its one-electron oxidation, L-ascorbyl radical) and L-dehydroascorbic acid [4, 27]. Vitamin $\mathrm{C}$ is water soluble and is responsible for many important functions in the body, including promotes detoxification of the body, is beneficial for maintaining immunity, protects the body against free radicals, stimulates collagen production, increases the bioavailability of non-heme iron, is involved in the synthesis of hormones $[9,20]$. Therefore, vitamin $\mathrm{C}$ is important for maintaining the health of the human body, preventing colds, cancer, cardiovascular diseases, hypertension, and supporting the healing of wounds $[1,3,18,21,23]$, but also an association has been shown between vitamin $\mathrm{C}$ intake and the prevention or treatment of Covid-19 infections $[5,22]$. There are studies that have also shown the effect of consuming foods rich in vitamin $\mathrm{C}$, i.e. vegetables and fruits, including juices, on the mental health of children and adolescents [11, 12].

The main source of vitamin $C$ are fresh vegetables, fruits and juices [17]. However vitamin $\mathrm{C}$ is readily oxidized and degraded at different rates depending on storage conditions. In the presence of oxygen ascorbic acid (AA) is oxidized to dehydroascorbic acid (DHAA), which has vitamin C activity [4]. Most of the commercially available juices are processed, and synthetic vitamin $\mathrm{C}$ is added during the process. There is little information about the content of vitamin $\mathrm{C}$ in fresh fruit juices, which do not contain any preservatives or sugar. They are produced even without pasteurization, which keeps the flavor and aroma of fresh fruits and vegetables.

Common fruit juices were associated with a significant reduction in risk and markers of cancer, improvement cardiovascular parameters, including reduced blood pressure and endothelial function, attenuated cognitive impairment of aging and neurodegeneration in humans. Beneficial effects on bone health, recurrent UTI in high risk women and pulmonary function were reported. All juices had significant anti-oxidant activity in vivo and in vitro in addition to other mechanisms related to disease risk such as cell signaling, inflammation, cell proliferation, and apoptosis. The possible health-related and disease prevention benefits of consuming $100 \%$ juice as part of a balanced diet should be appreciated [13]. These benefits are due, among others, the presence of vitamin $\mathrm{C}$, which is listed as the essential nutrient of fresh juices.

The aim of this study was to determine the content of L-ascorbic acid and the sum of ascorbic and dehydroascorbic acids in the ten types of fruit and vegetable juices, not preserved, purchased at retail, depending on its type and storage time.

\section{MATERIAL AND METHODS}

The juices from the two of the most important Polish producers were selected to the study. Fruit juices were obtained by directly mechanical extraction processes from the fragmented fruits and/or vegetables. They were naturally cloudy, unpasteurized, without dyes and preservatives. The finished product was packed in glass bottles in order to guarantee the maintenance of the original aroma and flavor of fresh fruits and vegetables. The technological process was conducted in accordance with the Hazard Analysis and Critical Control Points (HACCP) system and the standards of Good Agricultural Practice, and International Featured Standards.

Juices purchased twice at an interval of one month to check the repeatability of the vitamin $\mathrm{C}$ content in different batches of juices (test 1 and 2). To check the stability of ascorbic acid determination was repeated on a second batch of samples stored in the refrigerator after three days of opening the package (test 3). Manufacturers recommended storing the juices in the refrigerator, up to 4 days (except sauerkraut juice -7 days).

To study were selected following juices: sauerkraut and carrot mix, grapefruit, orange, apple, mandarin (Producer A); orange, apple, apple-quince, grapefruit, mandarin (Producer B).

\section{Determination of vitamin $C$}

The following reagents were used: L-dehydroascorbic acid (Cat.nr. 261556); Sodium dihydrogen phosphate $\left(\mathrm{NaH}_{2} \mathrm{PO}_{4}\right)$ (Cat.nr. S8282); 
Dodecyltrimetyl ammonium chloride (Cat.nr. 44242); Disodium ethylenediamine-N,N,N',N',-tetraacetic acid ( $\mathrm{Na}_{2}$ EDTA) (Cat.nr. E0399); Tris[2-carboxyethyl] phosphine hydrochloride (TCEP) (Cat.nr. C4706); Trizmabuffer (0,3M) (Cat.nr. T1449); meta-Phosphoric acid (MPA) (Cat.nr. 04103) were obtained from Sigma-Aldrich, USA. All reagents were of analytical grade purity. The mobile phase consisted of $2 \%$ of acetonitrile in the aqueous part prepared as follows: $2.5 \mathrm{mmol} / \mathrm{L} \mathrm{NaH}_{2} \mathrm{PO}_{4}, 2.5 \mathrm{mmol} / \mathrm{L}$ dodecyl-tri-methyl ammonium chloride and $1.25 \mathrm{mmol} / \mathrm{L} \mathrm{Na}_{2}$ EDTA dissolved in water.

Ascorbic acid (AA) and vitamin C (total ascorbic acid - TAA) were determined. The method of extraction was adapted from Karlsen et al. [16]. A juice sample $(0.5 \mathrm{~mL})$ were mixed with $10 \%$ MPA $(0.5 \mathrm{~mL})$ and centrifuged at $3500 \mathrm{x}$ g in $15 \mathrm{~min}$. Than two volumes of $300 \mu \mathrm{L}$ of the supernatant were used for the determination of AA and TAA.

The clear supernatant $(300 \mu \mathrm{L})$ was diluted with the aqueous part of the mobile phase $(300 \mu \mathrm{L})$, mix and centrifuged as previously. Than $100 \mu \mathrm{L}$ of supernatant was injected onto the HPLC column to AA determination. Second volume of supernatant $(300 \mu \mathrm{L})$ was mixed with the aqueous part of the mobile phase $(150 \mu \mathrm{L})$ and the solution $(150 \mu \mathrm{L})$ of the TCEP $(2.3 \mathrm{mmol} / \mathrm{L}$ of TCEP in trizmabuffer ( $800 \mathrm{mmol} / \mathrm{L} ; \mathrm{pH} \mathrm{9.0)}$. The sample was kept $7 \mathrm{~min}$ in the dark at room temperature for the reduction of dehydroascorbic acid (DHAA). After centrifugation $100 \mu \mathrm{L}$ of the supernatant was injected onto the HPLC column to TAA determination. The content of DHAA was calculated by subtracting the content of AA from TAA content.

Chromatographic analyzes were carried out using high-performance liquid chromatograph with a UVVIS detector (Gilson Company, Middleton, WI, USA). For AA and TAA separation the isocratic method was achieved on a Discovery ${ }^{\circledR} \mathrm{C} 18$ column $(5 \mu \mathrm{m}, 15 \mathrm{~cm}$ x 4,6 mm, SUPELCO; Supelco Analytical cat. no. 504955 , Bellafonte, PA, USA) connected with a precolumn of the same company. The flow rate was 0.75 $\mathrm{ml} / \mathrm{min}$, and the wavelength was $\lambda=264 \mathrm{~nm}$. Accuracy of the method was estimated by analysis of the standards of AA. The limit of quantification (LOQ) of the method was $44 \mu \mathrm{g}(0.25 \mu$ mola $) / \mathrm{L}$.

\section{Statistical analysis}

The mean and standard deviation of the three tests were calculated for the ascorbic acid, dehydroascorbic acid vitamin $\mathrm{C}$ content. Differences between the three testes (test 1 vs. test 2 and test 2 vs. test 3 ) were compared using the Mann-Whitney $\mathrm{U}$ test. The significance level of $p<0.05$ was used. The following software was used: Statistica 13.

\section{RESULTS}

The content of TAA in the analyzed samples of unpreserved juices was diversified. Regardless of the producer, the highest amounts of TAA were found in orange and grapefruit juice and mandarin juice, i.e. citrus juices in tests 1 and 2 in both producers $A$ and $\mathrm{B}$ (Table 1 and Table 2). This is about half the amount of fresh fruit in oranges, the content of TAA is 49 $\mathrm{mg} / 100 \mathrm{~g}$ of fresh weight of the product, in grapefruit $40 \mathrm{mg} / 100 \mathrm{~g}$, and in mandarins $30 \mathrm{mg} / 100 \mathrm{~g}$ [17]. The lowest TAA was found in sauerkraut and carrot brine and apple juice in tests 1 and 2 in both juice producers (Table 1 and Table 2). These values were two times lower than declared by the manufacturer.

The content of AA from two differentbatchesdiffered statistically significantly in grapefruit $(20.78 \pm 0.01 \mathrm{vs}$. $15.78 \pm 0.58)$ and apple juice $(2.77 \pm 0.25$ vs. $10.98 \pm 0.06)$ in producer A (Table 1) and orange $(15.93 \pm 0.39$ vs. $37.66 \pm 0.31$ ) in producer B (Table 2). The content of DHAA differed statistically significantly between the two batches of the tested juices (Table 1 and Table 2), except for the mandarin juice in producer B (Table 2). On the other hand, the content of TAA from two different batches differed statistically significantly in apple (5.33 \pm 0.95 vs. $11.68 \pm 0.30)$ and mandarin juice (17.05 \pm 0.37 vs. $13.38 \pm 0.02)$ in producer A (Table 1) and in orange juice $(20.36 \pm 0.84$ vs. $37.93 \pm 0.06)$ in producer B (Table 2).

After three days of refrigerated storage (test 3), the content of AA and TAA in apple juices was below the limit of quantification in both producers (Table $3)$. Moreover, the content of AA $(37.66 \pm 0.31$ vs. $28.43 \pm 0.63)$ and TAA $(37.93 \pm 0.06$ vs. $33.91 \pm 1.01)$ in orange juice producer B and AA content $(20.03 \pm 0.12$ vs. $15.70 \pm 0.18)$ in mandarin juice in producer $B$ decreased significantly (Table 3 ). However, after three days of refrigerated storage, the content of DHAA in grapefruit juice and mandarin juice increased in producer B and orange juice in both producers (Table 3).

The highest amounts of TAA were found in citrus juices: grapefruit, mandarin and orange (Table 3), which seem to be the most stable during storage, as the decrease in TAA was slight (up to $10 \%$ ).

\section{DISCUSSION}

The study showed that the highest content of TAA was found in citrus juices, i.e. grapefruit, orange and mandarin, and the lowest in sauerkraut and carrot juices and apple juice. Moreover, AA in apple juice showed the lowest stability.

Vitamin C-rich juices, like citrus juices, are also good sources of polyphenols. Vitamin C and polyphenols act synergistically and define the 

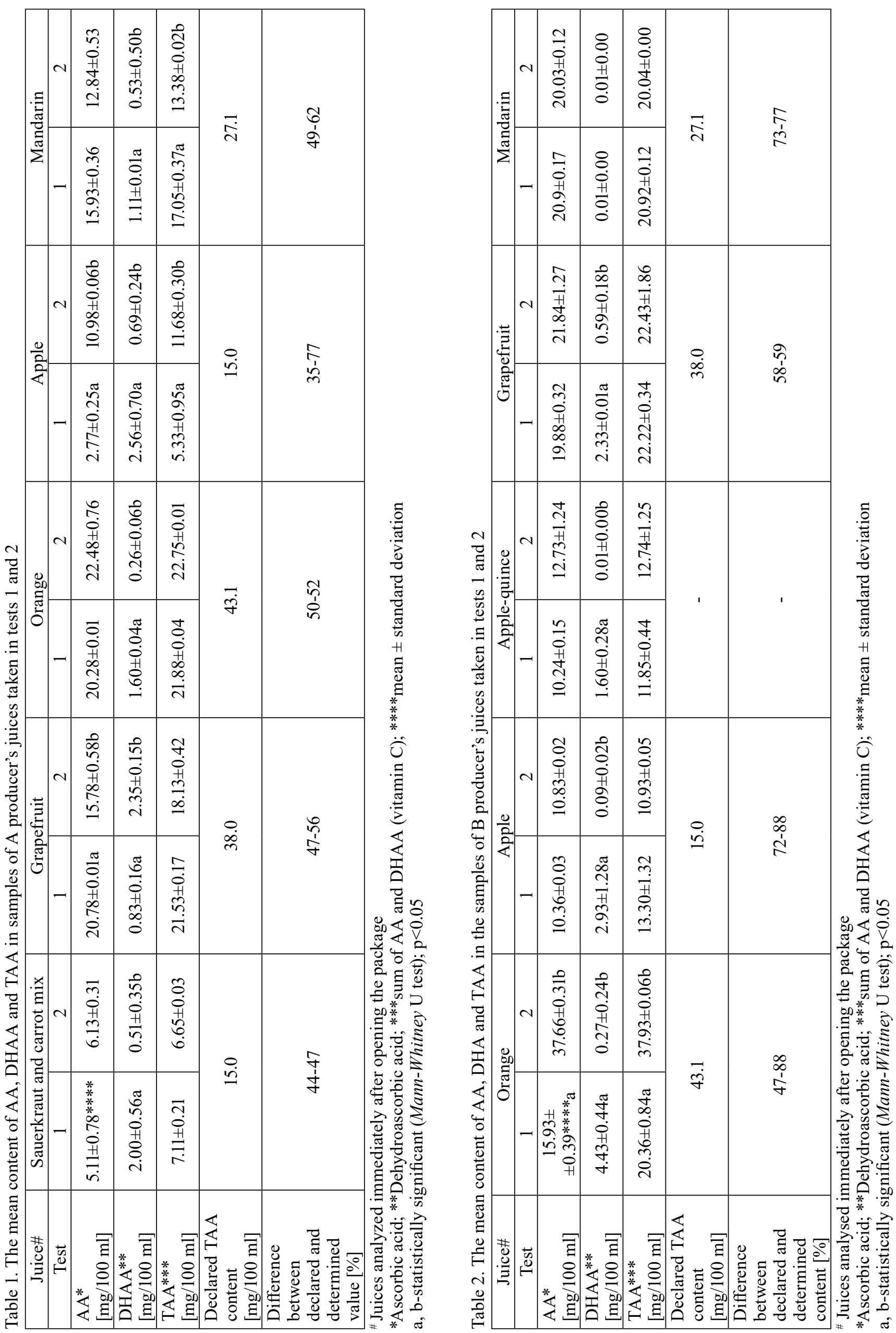

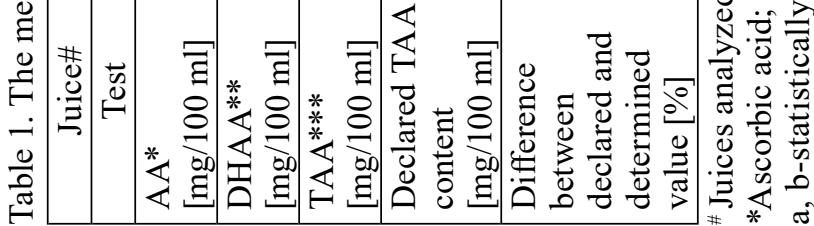


Table 3. Comparison of the average content of AA, DHAA and TAA in the juices of both producers (A and B) before and after three days of refrigerated storage

\begin{tabular}{|c|c|c|c|c|c|}
\hline Juice $^{\#}$ & Test & $\begin{array}{l}\text { AA* content }^{*} \\
{[\mathrm{mg} / 100 \mathrm{ml}]}\end{array}$ & $\begin{array}{c}\text { DHAA** content }^{* *} \\
{[\mathrm{mg} / 100 \mathrm{ml}]}\end{array}$ & $\begin{array}{c}\text { TAA*** content } \\
{[\mathrm{mg} / 100 \mathrm{ml}]}\end{array}$ & $\begin{array}{c}\text { Declared TAA } \\
\text { value }[\mathrm{mg} / 100 \mathrm{ml}]\end{array}$ \\
\hline \multirow{2}{*}{$\begin{array}{l}\text { Sauerkraut and carrot fix } \\
\text { Producer A }\end{array}$} & 2 & $6.13 \pm 0.31$ & $0.51 \pm 0.35$ & $6.65 \pm 0.03$ & \multirow{2}{*}{15.0} \\
\hline & 3 & $4.62 \pm 0.35$ & $0.82 \pm 0.10$ & $5.44 \pm 0.25$ & \\
\hline \multirow{2}{*}{$\begin{array}{l}\text { Grapefruit } \\
\text { Producer A }\end{array}$} & 2 & $15.48 \pm 0.58$ & $2.35 \pm 0.16$ & $18.13 \pm 0.42$ & \multirow{4}{*}{38.0} \\
\hline & 3 & $14.07 \pm 0.01$ & $2.76 \pm 0.05$ & $16.84 \pm 0.05$ & \\
\hline \multirow{2}{*}{$\begin{array}{l}\text { Grapefruit } \\
\text { Producer B }\end{array}$} & 2 & $21.84 \pm 1.27$ & $0.59 \pm 0.58^{\mathrm{a}}$ & $22.22 \pm 1.86$ & \\
\hline & 3 & $22.41 \pm 1.86$ & $2.06 \pm 0.11^{\mathrm{b}}$ & $24.47 \pm 1.98$ & \\
\hline \multirow{2}{*}{$\begin{array}{l}\text { Orange } \\
\text { Producer A }\end{array}$} & 2 & $22.48 \pm 0.25$ & $0.26 \pm 0.26^{\mathrm{a}}$ & $22.75 \pm 0.01$ & \multirow{4}{*}{43.1} \\
\hline & 3 & $20.61 \pm 0.11$ & $2.71 \pm 0.14^{b}$ & $23.33 \pm 0.26$ & \\
\hline \multirow{2}{*}{$\begin{array}{l}\text { Orange } \\
\text { Producer B }\end{array}$} & 2 & $37.66 \pm 0.31^{\mathrm{a}}$ & $0.27 \pm 0.24^{\mathrm{a}}$ & $37.93 \pm 0.06^{\mathrm{a}}$ & \\
\hline & 3 & $28.43 \pm 0.63^{b}$ & $5.48 \pm 0.38^{b}$ & $33.91 \pm 1.01^{\mathrm{b}}$ & \\
\hline \multirow{2}{*}{$\begin{array}{l}\text { Apple } \\
\text { Producer A }\end{array}$} & 2 & $10.98 \pm 0.06^{\mathrm{a}}$ & $0.69 \pm 0.24^{\mathrm{a}}$ & $11.68 \pm 0.30^{\mathrm{a}}$ & \multirow{4}{*}{15.0} \\
\hline & 3 & $<\mathrm{LOQ}^{\# \#}$ & $<$ LOQ & $<$ LOQ & \\
\hline \multirow{2}{*}{$\begin{array}{l}\text { Apple } \\
\text { Producer B }\end{array}$} & 2 & $10.83 \pm 0.02^{\mathrm{a}}$ & $0.09 \pm 0.02^{\mathrm{a}}$ & $10.93 \pm 0.05^{\mathrm{a}}$ & \\
\hline & 3 & $<\mathrm{LOQ}$ & $<\mathrm{LOQ}$ & $<\mathrm{LOQ}$ & \\
\hline \multirow{2}{*}{$\begin{array}{l}\text { Apple-quince } \\
\text { Producer B }\end{array}$} & 2 & $12.73 \pm 1.24^{\mathrm{a}}$ & $0.01 \pm 0.01^{\mathrm{a}}$ & $12.74 \pm 1.25^{\mathrm{a}}$ & \multirow{2}{*}{-} \\
\hline & 3 & $<\mathrm{LOQ}$ & $<\mathrm{LOQ}$ & $<\mathrm{LOQ}$ & \\
\hline \multirow{2}{*}{$\begin{array}{l}\text { Mandarin } \\
\text { Producer A }\end{array}$} & 2 & $12.84 \pm 0.53$ & $0.53 \pm 0.50$ & $13.38 \pm 0.02$ & \multirow{4}{*}{27.1} \\
\hline & 3 & $12.28 \pm 0.36$ & $0.98 \pm 0.37$ & $13.26 \pm 0.01$ & \\
\hline \multirow{2}{*}{$\begin{array}{l}\text { Mandarin } \\
\text { Producer B }\end{array}$} & 2 & $20.03 \pm 0.12^{\mathrm{a}}$ & $0.01 \pm 0.01^{\mathrm{a}}$ & $20.04 \pm 0.12$ & \\
\hline & 3 & $15.70 \pm 0.18^{b}$ & $1.79 \pm 0.49^{b}$ & $17.49 \pm 0.30$ & \\
\hline
\end{tabular}

\# Juices analyzed immediately after opening the package (Test 2) and after three days of refrigerated storage (Test 3)

\# LOQ - limit of quantification - $44 \mu \mathrm{g}(0.25 \mu \mathrm{mola}) / \mathrm{L}$

* AA - Ascorbic acid; ** DHAA - Dehydroascorbic acid ; *** TAA - sum of AA and DHAA (vitamin C)

$\mathrm{a}, \mathrm{b}$ - statistically significant (Mann-Whitney $\mathrm{U}$ test); $\mathrm{p}<0.05$

antioxidant properties of juices. Many studies have shown that bioactive compounds, for example, polyphenols, and so on can play an important role in reducing oxidative stress and protect against various diseases [19]. In a study by Soriano-Maldonado et al. [24] showed that a joint consumption of apple juice natural antioxidants such as vitamin $\mathrm{C}$ and polyphenols might provide mild favorable effects on cardiometabolic markers, as compared to apple polyphenols alone.

The amounts declared by producers do not differ significantly from the expected vitamin $\mathrm{C}$ content in fresh fruit. However, as shown in this study, the TAA content in unfixed juices was lower. AA degradation occurs in both the aerobic and anaerobic pathways [14] and depends on many factors such as oxygen, light, heat, temperature, and storage time $[7,8,26]$. As demonstrated by Johnston and Bowling [15], readyto-eat orange juices had a higher concentration of oxidized vitamin $\mathrm{C}$ compared to orange juices from frozen concentrates, but the rate of vitamin $\mathrm{C}$ decrease after opening was similar for all juices, about $2 \%$ per day. Taking into account the factors influencing the vitamin $\mathrm{C}$ content in the finished product: on the one hand, the fruit varieties, their ripeness and storage method, and on the other hand, the access of oxygen, light during production processes and the method of storage, transport and display on store shelves, there should be a batch of juices for the determination of vitamin $\mathrm{C}$ content.

The research also shows that the lowest content of TAA was in the juice of sauerkraut and carrots and apple. Moreover, AA in apple juice showed the lowest stability. It seems that in the production of fruit juices, the possibility of naturally protecting AA in apple juice by the addition of citrus juice or other fruits, vegetables $[2,10]$ or by using a gentle technology in the production process should be considered $[6,25]$.

\section{CONCLUSIONS}

Based on the research, it can be concluded that from the nutritional point of view, unpasteurized juices, mainly from citrus fruits, can be a valuable source of TAA. It seems that in the production of fruit juices, the possibility of naturally protecting AA in apple juice by the addition of citrus juice or other fruits, vegetables. The conducted studies should be treated as a pilot, 
and to draw clear conclusions, systematic long-term studies and a larger number of samples for analysis are necessary.

\section{Conflict of interests}

The authors declare no conflict of interests.

\section{REFERENCES}

1. Ang A., Pullar J.M., Currie M.J., Vissers M.C.M.: Vitamin $\mathrm{C}$ and immune cell function in inflammation and cancer. Biochem Soc Trans 2018;46(5):1147-1159, doi: 10.1042/BST20180169.

2. Biegańska-Marecik R., Radziejewska-Kubzdela E., Marecik R.: Characterization of phenolics, glucosinolates and antioxidant activity of beverages based on apple juice with addition of frozen and freeze-dried curly kale leaves (Brassica oleracea L. var. acephala L.). Food Chem 2017;230:271-280, doi: 10.1016/j.foodchem.2017.03.047.

3. Carr A.C., Maggini S.: Vitamin C and Immune Function. Nutrients 2017;9(11):1211, doi: 10.3390/nu9111211.

4. Cisternas P., Silva-Alvarez C., Martínez F., Fernandez E., Ferrada L., Oyarce K., Salazar K., Bolaños J.P., Nualart F.: The oxidized form of vitamin C, dehydroascorbic acid, regulates neuronal energy metabolism. J Neur 2014;129(4):663-671, doi: 10.1111/ jnc. 12663.

5. Colunga Biancatelli R.M.L., Berrill M., Catravas J.D., Marik P.E.: Quercetin and Vitamin C: An Experimental, Synergistic Therapy for the Prevention and Treatment of SARS-CoV-2 Related Disease (COVID-19). Front Immunol 2020;11:1451, doi: 10.3389/fimmu.2020.01451.

6. Dziadek K., Kopeć A., Dróżdż T., Kiełbasa P., Ostafin M., Bulski K., Oziembłowski M.: Effect of pulsed electric field treatment on shelf life and nutritional value of apple juice. J Food Sci Technol 2019;56(3):11841191, doi: 10.1007/s13197-019-03581-4.

7. Fellers P.J.: Shelf life and quality of freshly squeezed, unpasteurized, polyethylene-bottled citrus juice. J Food Scien 1988;53(6):1699-1702. https://doi org/10.1111/j.1365-2621.1988.tb07819.x

8. Gordon, L.R., Samaniego-Esguerra, M.C.: Effect of soluble solids and temperature on ascorbic acid degradation in lemon juice stored in glass bottles. J Food Quality 1990;13:361-374. https://doi. org/10.1111/j.1745-4557.1990.tb00032.x

9. Granger M., Eck P.: Dietary Vitamin C in Human Health. Adv Food Nutr Res 2018; 83:281-310, doi: 10.1016/bs.afnr.2017.11.006.

10. Grobelna A., Kalisz S., Kieliszek M.: The Effect of the Addition of Blue Honeysuckle Berry Juice to Apple Juice on the Selected Quality Characteristics, Anthocyanin Stability, and Antioxidant Properties. Biomolecules 2019;9(11):744, doi: 10.3390/biom9110744.

11. Guzek D., Głabska D., Groele B., Gutkowska K.: Fruit and vegetables intake in adolescents and mental health: a systematic review. RoczPanstwZaklHig 2020;71(1):1525. https://doi.org/10.32394/rpzh.2019.0097

12. Guzek D., Głąska D., Groele B., Gutkowska K.: Role of fruit and vegetables for the mental health of children: a systematic review. Rocz Panstw Zakl Hig 2020;71(1):513, https://doi.org/10.32394/rpzh.2019.0096

13. Hyson D.A.: A comprehensive review of apples and apple components and their relationship to human health. Adv Nutr 2011;2(5):408-420, doi: 10.3945/an.111.000513.

14. Johnson J.R., Braddock R.J., Chen C.S.: Kinetics of ascorbic acid loss and non enzymatic browning in orange juice serum: Experimental rate constants. Journal of Food Science 1995;60(3):502-505, doi: 10.1111/j.1365-2621.1995.tb09812.x.

15. Johnston C.S., Bowling D.L.: Stability of ascorbic acid in commercially available orange juices. J Am Diet Assoc 2002;102:525-529, doi: 10.1016/s0002-8223(02)90119-7.

16. Karlsen A., Blomhoff R., Gundersen T.E.: Highthroughput analysis of vitamin $\mathrm{C}$ in human plasma with the use of HPLC with monolithic column and UV-detection. J Chromatogr B Analyt Technol Biomed Life Sci 2005;824(1-2):132-138, doi: 10.1016/j. jchromb.2005.07.008.

17. Kunachowicz H., Przygoda B., Nadolna I., Iwanow $K$. : Tabele składu i wartości odżywczej żywności”. Wydawnictwo PZWL, 2017 (in Polish).

18. Morelli M.B., Gambardella J., Castellanos V., Trimarco V., Santulli G.: Vitamin C and Cardiovascular Disease: An Update. Antioxidants (Basel) 2020;9(12):1227, doi: 10.3390/antiox9121227.

19. Nowak D., Gośliński M., Wojtowicz E., Przygoński K.: Antioxidant Properties and Phenolic Compounds of Vitamin C-Rich Juices. Health, Nutrition, \& Food 2018; 8, doi.org/10.1111/1750-3841.14284.

20. Padayatty S.J., Levine M.: Vitamin C: the known and the unknown and Goldilocks. Oral Dis 2016;22(6):46393, doi: 10.1111/odi.12446.

21. Pullar J.M., Carr A.C., Vissers M.C.M.: The Roles of Vitamin C in Skin Health. Nutrients 2017; 9(8): 866, doi: 10.3390/nu9080866.

22. Shakoor H., Feehan J., Al Dhaheri A.S., Ali H.I., Platat C., Ismail L.C., Apostolopoulos V., Stojanovska L.: Immune-boosting role of vitamins $\mathrm{D}, \mathrm{C}, \mathrm{E}$, zinc, selenium and omega-3 fatty acids: Could they help against COVID-19? Maturitas 2021;143:1-9, doi: 10.1016/j.maturitas.2020.08.003.

23. Shenoy N., Creagan E., Witzig T., Levine M.: Ascorbic Acid in Cancer Treatment: Let the Phoenix Fly. Cancer Cell 2018; 34(5): 700-706, doi: 10.1016/j. ccell.2018.07.014.

24. Soriano-Maldonado A., Hidalgo M., Arteaga P., de Pascual-Teresa S., Nova E.: Effects of regular consumption of vitamin C-rich or polyphenol-rich apple juice on cardiometabolic markers in healthy adults: a randomized crossover trial. Eur J Nutr 2014;53(8):16451657, doi: 10.1007/s00394-014-0670-7.

25. Suárez-Jacobo A., Rüfer C.E, Gervilla R., Guamis B., Roig-Sagués A.X., Saldo J.: Influence of ultrahigh pressure homogenisation on antioxidant capacity, polyphenol and vitamin content of clear apple juice. 
Food Chem 2011;127(2): 447-454, doi: 10.1016/j. foodchem.2010.12.152.

26. Tikekar R.V., Anantheswaran R.C., Laborde L.F.: Ascorbic acid degradation in a model apple juice system and in apple juice during ultraviolet processing and storage. J Food Sci 2011;76, 62 - 71, doi: 10.1111/j.17503841.2010.02015.x.

27. Zou W., Liu L., Chen J.: Structure, mechanism and regulation of an artificial microbial ecosystem for vitamin C production. Crit Rev Microbiol 2013; 39(3): 247-55, doi: 10.3109/1040841X.2012.706250.

Received: 21.09.2021

Accepted: 02.11.2021

Published online first: 09.11.2021 